Chapter 3

\title{
Barriers and Opportunities
}

This chapter should be cited as

Sakaguchi K. and V. Anbumozhi (2015), 'Barriers and Opportunities', in Sustainability Assessment of Utilising Conventional and New Type Geothermal Resources in East Asia. ERIA Research Project Report 2014-41, Jakarta: ERIA, pp.27-55. Available at: http://www.eria.org/RPR FY2014 No.41 Chapter 3.pdf 


\section{Chapter 3 \\ Barriers and Opportunities}

\subsection{Technical and Other Barriers}

\subsubsection{Technical barriers}

\section{a) Power generation}

Table 3.1-1 shows technical barriers for geothermal power generation for three stages: exploration, installation (development), and sustainable use based on the answer from each country.

Common problems for exploration for power generation are:

- Drilling success: testing of new methods and applications to increase the success rate of exploration wells such as remote sensing, 3D inversion of MT, radon survey, and joint geophysical imaging,

- Geophysical survey: see Table 3.1-1, and

- Public acceptance: national and local governments should support RE projects.

Common problems for installation of power generation are:

- Drilling success of production well,

- Reservoir characterisation, and

- Acidic and high silica fluid.

Common problems for sustainability of power generation are:

- Sustainable reinjection: experience in different geothermal reservoirs,

- Reinjection fluid return (short circuit),

- Decline of production wells (pressure drawdown),

- Scaling in injection wells,

- Acidic fluid corrosion,

- Shallow groundwater into reservoir, and

- Geo-hazard (landslide, subsidence, typhoon, volcanic eruption, earthquake).

For all exploration, installation and sustainable power generation, more research fund is needed. International collaborative cooperation in R\&D on solving those problems above is needed. 
Table 3.1-1. Technical Barriers for Geothermal Power Generation

for Different Stages

\begin{tabular}{|c|c|c|c|}
\hline Country & Exploration & $\begin{array}{c}\text { Installation } \\
\text { (development) }\end{array}$ & Sustainable use \\
\hline China & $\begin{array}{l}\text { Well logging } \\
\text { instruments and } \\
\text { circulating technique in } \\
\text { high temperature } \\
\text { geothermal drilling }\end{array}$ & $\begin{array}{l}\text { Domestic product limited } \\
\text { in } 5 \mathrm{MW} \text {, no big capacity. }\end{array}$ & $\begin{array}{l}\text { Sustainable reinjection } \\
\text { has not yet done }\end{array}$ \\
\hline Indonesia & $\begin{array}{l}\text { Low drilling success } \\
\text { ratio }\end{array}$ & $\begin{array}{l}\text { Fluid characteristics } \\
\text { (acidic fluid, high silica) }\end{array}$ & $\begin{array}{l}\text { Decline of production } \\
\text { well ( } 5 \text { to } 10 \% \text { per year in } \\
\text { average) and reinjection } \\
\text { well (scaling); Geo- } \\
\text { hazards (landslide, } \\
\text { earthquake, volcanic } \\
\text { activity) }\end{array}$ \\
\hline Japan & $\begin{array}{l}\text { Limit of geophysical } \\
\text { methods (Resistivity } \\
\text { image does not always } \\
\text { show reservoir shape.) }\end{array}$ & $\begin{array}{l}\text { Success rate of } \\
\text { production well drilling } \\
\text { Minimisation of } \\
\text { environmental impact }\end{array}$ & $\begin{array}{l}\text { Scale, pressure decline, } \\
\text { short circuit (reinjection } \\
\text { fluid control) }\end{array}$ \\
\hline South Korea & $\begin{array}{l}\text { Lack of deep well } \\
\text { information, such as } \\
\text { temperature, stress and } \\
\text { fracture distribution }\end{array}$ & $\begin{array}{l}\text { Lack of experience in } \\
\text { deep drilling, } \\
\text { measurement and } \\
\text { reservoir engineering } \\
\text { Difficulty of securing } \\
\text { proper technical services } \\
\text { and procurements }\end{array}$ & - \\
\hline Philippines & $\begin{array}{l}\text { Environmental permits } \\
\text { (tree cutting permit, } \\
\text { access to national } \\
\text { parks, etc.), social } \\
\text { acceptance and access } \\
\text { permits, insurgents, } \\
\text { finding good } \\
\text { permeability and high } \\
\text { temperature for the } \\
\text { first three exploration } \\
\text { wells. }\end{array}$ & $\begin{array}{l}\text { Simultaneous } \\
\text { sustainability testing, } \\
\text { establishing production } \\
\text { sharing and injection } \\
\text { interference, drilling } \\
\text { interference. Matching of } \\
\text { right power conversion } \\
\text { system with reservoir } \\
\text { characteristics to } \\
\text { optimise resource and } \\
\text { efficiency }\end{array}$ & $\begin{array}{l}\text { Reservoir drawdown; } \\
\text { mineral scaling in wells, } \\
\text { surface pipeline network } \\
\text { and reservoir; acidity of } \\
\text { production fluids and } \\
\text { attendant corrosion; } \\
\text { reinjection returns; influx } \\
\text { of shallow groundwater } \\
\text { into reservoir; landslide } \\
\text { risks and surface } \\
\text { facilities' damages due to } \\
\text { super-typhoon }\end{array}$ \\
\hline Thailand & $\begin{array}{l}\text { Geophysical survey and } \\
\text { drilling technique }\end{array}$ & - & - \\
\hline Viet Nam & $\begin{array}{l}\text { Geophysical survey, } \\
\text { drilling, reservoir } \\
\text { modelling }\end{array}$ & - & - \\
\hline
\end{tabular}

Source: Compiled by authors. 


\section{Direct use (conventional)}

Table 3.1-2 shows technical barriers for conventional direct use for three stages; exploration, installation (development) and sustainable use based on the answer from each country. Technical problems for direct use are:

- Success rate of well drilling,

- Scales,

- Reinjection, and

- Low-permeability.

International collaborative cooperation in R\&D on solving those problems above is needed. Another point is that many countries gave NA for direct use, which shows that advantage of direct use is not well recognised and systematic use is not very common in these countries that is related to:.

- Public awareness,

- Lack of system designer, and

- Lack of multi-purpose use and cascade use.

Geothermal experts should act to raise public awareness. Governments should put incentives to use thermal use of geothermal energy. (In South Korea, renewable heat obligation, or RHO, is planned to be enacted in the near future).

Table 3.1-2. Technical Barriers for Direct Use for Different Stages

\begin{tabular}{|l|c|c|l|}
\hline Country & \multicolumn{1}{|c|}{ Exploration } & $\begin{array}{c}\text { Installation } \\
\text { (development) }\end{array}$ & \multicolumn{1}{|c|}{ Sustainable use } \\
\hline China & $\begin{array}{l}\text { Successful rate for } \\
\text { production well drilled } \\
\text { in fractured reservoir }\end{array}$ & - & $\begin{array}{l}\text { Reinjection for sandstone } \\
\text { reservoir }\end{array}$ \\
\hline Indonesia & - & - & - \\
\hline Japan & - & - & $\begin{array}{l}\text { Scale, interference of wells } \\
\text { (hot spring) }\end{array}$ \\
\hline South Korea & - & - & $\begin{array}{l}\text { Mostly, insufficient flow rate } \\
\text { due to low permeability of } \\
\text { fractured reservoir in } \\
\text { crystalline rocks }\end{array}$ \\
\hline Philippines & - & - & - \\
\hline Thailand & - & - & $\begin{array}{l}\text { How to use energy } \\
\text { efficiently }\end{array}$ \\
\hline Viet Nam & - & - & \\
\hline
\end{tabular}

Source: Compiled by authors. 


\section{b) GSHP}

Table 3.1-3 shows technical barriers for GSHP for three stages: exploration, installation, and sustainable use based on the answers from each country.

Table 3.1-3. Technical Barriers for GSHP for Different Stages

\begin{tabular}{|c|c|c|c|}
\hline Country & Exploration & Installation & Sustainable Use \\
\hline China & - & - & - \\
\hline Indonesia & - & - & - \\
\hline Japan & $\begin{array}{l}\text { Geological and } \\
\text { hydrological } \\
\text { database, } \\
\text { especially, } \\
\text { estimation of } \\
\text { groundwater flux }\end{array}$ & Drilling cost & $\begin{array}{l}\text { Control of annual heat } \\
\text { exchange balance } \\
\text { (extraction and/or } \\
\text { injection) }\end{array}$ \\
\hline South Korea & - & $\begin{array}{l}\text { Lack of information } \\
\text { on subsurface } \\
\text { thermal properties } \\
\text { associated with } \\
\text { hydrology }\end{array}$ & $\begin{array}{l}\text { Lack of long-term } \\
\text { performance analysis } \\
\text { in conjunction with } \\
\text { monitoring of } \\
\text { subsurface } \\
\text { temperature and/or } \\
\text { water level variation }\end{array}$ \\
\hline Philippines & - & - & - \\
\hline Thailand & Case study & - & - \\
\hline Viet Nam & $\begin{array}{l}\text { Need to do the } \\
\text { detail research }\end{array}$ & $\begin{array}{l}\text { Need to have one } \\
\text { pilot installation }\end{array}$ & - \\
\hline
\end{tabular}

Source: compiled by authors

Problems for GSHP are derived from:

- Lack of case study (showing successful case),

- Lack of hydrogeological database,

- Drilling cost, and

- Lack of information on long-term performance (for example, monitoring subsurface temperature).

Governments should fund domestic R\&D for hydrogeological studies, case studies, and long-term monitoring. Also, international research collaboration is essential to share the knowledge obtained in each country. Drilling cost may be reduced by both mass production and technical improvement suitable for each local geology, which means that drilling cost can also be reduced by the accumulation of knowledge and number of 
installations supported by R\&D on case studies, hydrogeological studies, and long-term monitoring.

\section{Recommendation to policymakers}

- For promotion of geothermal power generation, governments should support research activities for all three stages of exploration, development, and sustainable use. International collaborative cooperation in R\&D on solving those problems above should also be supported.

- For direct use, governments should put incentives to use thermal use of geothermal energy.

- For promotion and sustainable use of GSHP, governments should support R\&D on hydrogeological studies, case studies, and long-term monitoring. Also governments should encourage international research collaboration on these topics.

\subsubsection{Other barriers}

Table 3.1-4 shows competitors to geothermal energy use in each country, including geothermal power, direct use, and GSHP. Natural gas and other renewable energies are competitors for both power generation and GSHP.

Table 3.1-4. Other Barriers for Geothermal Energy Use: Competitors

\begin{tabular}{|l|l|}
\hline \multicolumn{1}{|c|}{ Country } & \multicolumn{1}{c|}{ Competitors } \\
\hline China & $\begin{array}{l}\text { For power generation, hydropower in Yunnan province (South Western } \\
\text { China). }\end{array}$ \\
\hline Indonesia & For power generation, cheaper coal energy sources, subsidies on diesel oil. \\
\hline Japan & $\begin{array}{l}\text { For GSHP, air-source heat pump (normal air-conditioner using electricity) is } \\
\text { a strong competitor. }\end{array}$ \\
\hline South Korea & For GSHP, natural gas is the strongest competitor, especially for heating. \\
\hline Philippines & For power generation, natural gas. \\
\hline Thailand & For power generation, solar farms, biomass, and wind energies. \\
\hline Viet Nam & NA \\
\hline
\end{tabular}

GSHP = ground source heat pump, NA = not applicable

Source: Compiled by authors. 


\subsection{Environmental Constraints}

Tables 3.2-1 to 3.2-3 show the current status of environmental protection legislation related to geothermal development in each country.

Table 3.2-1. Environmental Protection Legislation

\section{Related to Geothermal Development}

\begin{tabular}{|l|l|}
\hline \multicolumn{1}{|c|}{ Country } & \multicolumn{1}{|c|}{ Environmental Protection Legislation } \\
\hline China & Law of Environmental Protection of China. Covers air, water, and land. \\
\hline Indonesia & $\begin{array}{l}\text { Environmental Law No. 32 Year 2009 and Presidential Regulation on } \\
\text { Environmental Permits No. 27 Year 2012 containing legislation on water, } \\
\text { landscape, noise, etc. }\end{array}$ \\
\hline Japan & $\begin{array}{l}\text { Environmental Impact Assessment Law for development; Hot Spring Law } \\
\text {-for drillings; National Park Law - Soil and Rock extraction }\end{array}$ \\
\hline South Korea & $\begin{array}{l}\text { Groundwater Law - all boreholes must be reported on depth and purpose } \\
\text { prior to drilling Act of 2004 (RA 9275) }\end{array}$ \\
\hline Philippines & $\begin{array}{l}\text { Water Quality Management Act } \\
\text { Philippine Clean Air Act of 1999 (RA 8749); National Land Use Bill } \\
\text { (pending) }\end{array}$ \\
\hline Thailand & $\begin{array}{l}\text { Protection of national parks (no development in national parks) } \\
\text { Decisions under this law are issued by the government or the Ministry of } \\
\text { Natural Resources and Environment. }\end{array}$ \\
\hline Viet Nam &
\end{tabular}

Source: Compiled by authors.

Table 3.2-2. Requirement of Environmental Impact Statements and/or Reports

\begin{tabular}{|l|l|}
\hline \multicolumn{1}{|c|}{ Country } & \multicolumn{1}{|c|}{ Requirement of Environmental Impact Statements/Reports } \\
\hline China & $\begin{array}{l}\text { Yes, for any project of industry, energy and renewable energy, an } \\
\text { Environmental Impact Estimation Report is required before construction. }\end{array}$ \\
\hline Indonesia & $\begin{array}{l}\text { Yes, based on Presidential Regulation on Environmental Permits No. 27 } \\
\text { Year 2012. The lower limit is } \geq 55 \mathrm{MWe} \text {. For small-scale (<55 MWe) the } \\
\text { environmental monitoring system is needed. }\end{array}$ \\
\hline Japan & $\begin{array}{l}\text { Yes. Environmental Assessment Law requests reports for GPPs of } \geq 10 \\
\text { MWe. }\end{array}$ \\
\hline South Korea & $\begin{array}{l}\text { Yes. According to Groundwater law, results of environmental impact } \\
\text { assessment must be submitted if somebody is to use groundwater. }\end{array}$ \\
\hline Philippines & $\begin{array}{l}\text { Yes. Certificate of non-coverage for 3G. For <50 MWe, ECC and IEE checklist } \\
\text { report is required. For }>50 \text { MWe, ECC and EIS report is required. }\end{array}$ \\
\hline Thailand & No \\
\hline Viet Nam & $\begin{array}{l}\text { Yes. Depending on the scale of the power projects but there is no specific } \\
\text { regulation for geothermal power project yet. }\end{array}$ \\
\hline
\end{tabular}

GPP $=$ Geothermal Power Plant, $\mathrm{MWe}=$ megawatt electric, $3 \mathrm{G}=$ geological, geochemical and geophysical surveys, $\mathrm{ECC}=$ Environmental Compliance Certificate, EIS $=$ Environmental Impact Statement, IEE = Initial Environmental Examination

Source: Compiled by authors. 
Table 3.2-3. Other Environmental Protection Matters

\begin{tabular}{|c|l|}
\hline Country & \multicolumn{1}{|c|}{ Others (applicable permits, etc.) } \\
\hline China & $\begin{array}{l}\mathrm{CO}_{2} \text { tax will be implemented popularly after experimental implementation } \\
\text { of } \mathrm{CO}_{2} \text { trade in } 7 \text { cities and provinces. }\end{array}$ \\
\hline Indonesia & $\begin{array}{l}\text { Geothermal development should meet spatial use managements especially } \\
\text { as regulated by: } \\
\text { 1. Forestry Law No. 41 Year 1999 containing legislation on forest for other } \\
\text { uses, protection and conservation areas. } \\
\text { 2. Law on Spatial Planning No. 26 Year 2007 containing legislation on } \\
\text { planning for spatial use and protection. }\end{array}$ \\
\hline Philippines & $\begin{array}{l}\text { Pollution Control, Watershed Management } \\
\text { Social Acceptability - National Integrated Protected Areas System, National } \\
\text { Commission on Indigenous People }\end{array}$ \\
\hline Viet Nam & $\begin{array}{l}\text { Not applicable yet, but the environmental law also encourages the } \\
\text { development of renewable energy. }\end{array}$ \\
\hline
\end{tabular}

Source: Compiled by authors.

\section{Summary of current status}

- All countries have existing laws governing national parks and maintaining air, water standards and land use. Such laws are important to protect local environment but that prevent geothermal developments.

- $\mathrm{A} \mathrm{CO}_{2}$ tax law will be implemented in China and also forthcoming for the Philippines in 2015.

\section{Recommendation to policymakers}

- Enactment of a law inside a national park to isolate a certain area for geothermal development (Energy Zone) and to balance energy development with national forest conservation is recommended to keep the balance between geothermal development and environmental protection.

- All counties should issue $\mathrm{CO}_{2}$ tax law for promotion of RE development to preserve the global environment.

\subsection{Social and Political Issues (Social Awareness)}

Table 3.3-1 shows the level of recognition on geothermal energy in each country. There is a clear tendency that in countries that have many geothermal power plants but not many GSHPs, such as in Indonesia, Japan, and Philippines, geothermal power generation is widely recognised, while GSHP is not. On the other hand, in countries where GSHP has an installation rate but not geothermal power plants, such as in China and South Korea, GSHP is widely recognised while geothermal power generation is not. Education may be needed for poorly installed countries to promote geothermal energy 
use. (Recommendations to policymakers on this matter will be given in section 3.7.)

According to the answers from geothermal power producing countries, most typically in the Philippines, it seems involvement of the local population is becoming more important for geothermal development projects.

Table 3.3-1. Is Geothermal Energy Recognised?

\begin{tabular}{|c|c|c|c|c|c|c|c|c|c|c|c|c|}
\hline \multirow[t]{2}{*}{ Country } & \multicolumn{3}{|c|}{$\begin{array}{l}\text { Recognised in } \\
\text { general public? }\end{array}$} & \multicolumn{3}{|c|}{$\begin{array}{l}\text { Recognised in } \\
\text { decision-making } \\
\text { level? }\end{array}$} & \multicolumn{3}{|c|}{$\begin{array}{l}\text { Are benefits and } \\
\text { advantages } \\
\text { known? }\end{array}$} & \multicolumn{3}{|c|}{$\begin{array}{l}\text { To what extent local } \\
\text { population } \\
\text { informed/involved } \\
\text { in project } \\
\text { development? }\end{array}$} \\
\hline & PG & DU & GSHP & PG & DU & GSHP & PG & DU & GSHP & PG & DU & GSHP \\
\hline China & $\Delta$ & 0 & 0 & $\Delta$ & $\Delta$ & 0 & $\Delta$ & $\Delta$ & 0 & $x$ & $\Delta$ & $\Delta$ \\
\hline Indonesia & $\Delta$ & $\Delta$ & $x$ & O & $x$ & $x$ & $\Delta$ & $\Delta$ & $x$ & $\Delta$ & $\Delta$ & $x$ \\
\hline Japan & $\Delta$ & $x$ & $\Delta$ & 0 & $x$ & $\Delta$ & 0 & $x$ & $\Delta$ & $\Delta$ & $x$ & $x$ \\
\hline South Korea & $x$ & $x$ & $\Delta$ & $\Delta$ & $x$ & 0 & $\Delta$ & $x$ & $\Delta$ & $x$ & $x$ & $x$ \\
\hline Philippines & 0 & $x$ & $x$ & 0 & $x$ & $x$ & 0 & $x$ & $x$ & 0 & $x$ & $x$ \\
\hline Thailand & $\Delta$ & $x$ & $x$ & $\Delta$ & $x$ & $x$ & 0 & $x$ & $x$ & $x$ & $x$ & $x$ \\
\hline Viet Nam & $\Delta$ & 0 & $x$ & $\Delta$ & $\Delta$ & $x$ & $\Delta$ & $\Delta$ & $x$ & $x$ & 0 & $x$ \\
\hline
\end{tabular}

Note: $P G=$ power generation: $\mathrm{DU}=$ direct use: GSHP = ground source heat pump.

$\mathrm{O}=$ Well recognised, $\Delta=$ Somewhat, $\mathrm{x}=$ Negligible.

Source: Compiled by authors.

\section{Recommendation to policymakers}

Governments should develop supportive systems for the involvement of the local population to geothermal development projects. 


\subsection{Legal Matters}

Tables 3.4-1 to 3.4-45show geothermal legislation system in each country.

All countries except South Korea have legislation for power generation while most countries don't have legislation for GSHP. Direct use is in between.

\section{Recommendation to policymakers}

A one-stop-shop type of legislation including environmental permission is desirable.

Table 3.4-1. Does a Specific Geothermal Legislation Exist?

\begin{tabular}{|c|c|c|c|}
\hline & Power generation & Direct use & GSHP \\
\hline China & $\begin{array}{l}\text { Yes, Renewable Energy } \\
\text { Law of } 2009 \text { version }\end{array}$ & $\begin{array}{c}\text { Yes, Renewable Energy } \\
\text { Law of } 2009 \text { version }\end{array}$ & $\begin{array}{l}\text { Yes, when using open } \\
\text { system of groundwater }\end{array}$ \\
\hline Indonesia & Yes & Yes & No \\
\hline Japan & Yes, for drilling only & Yes, for drilling only & Yes, for drilling only \\
\hline South Korea & No & No & No \\
\hline Philippines & $\begin{array}{c}\text { Yes, Renewable Energy } \\
\text { Act of } 2008\end{array}$ & NA & NA \\
\hline Thailand & No & No & No \\
\hline Viet Nam & No & No & No \\
\hline
\end{tabular}

NA = not applicable

Source: Compiled by authors. 
Table 3.4-2. Part of Mining Legislation or Separate Legislation?

\begin{tabular}{|c|c|c|c|}
\hline Country & Power generation & Direct use & GSHP \\
\hline China & $\begin{array}{l}\text { Yes, part of mining } \\
\text { legislation }\end{array}$ & $\begin{array}{l}\text { Yes, part of mining } \\
\text { legislation }\end{array}$ & $\begin{array}{l}\text { When GSHP uses } \\
\text { groundwater as } \\
\text { source, needs } \\
\text { licence from } \\
\text { administration of } \\
\text { water }\end{array}$ \\
\hline Indonesia & $\begin{array}{l}\text { Separate law: } \\
\text { Geothermal Law No. } 27 \\
\text { Year } 2003 \text {, followed by } \\
\text { Government Regulation } \\
\text { No. } 59 \text { Year 2007, and } \\
\text { some ministerial } \\
\text { regulations and decrees }\end{array}$ & $\begin{array}{l}\text { Legislated in GL27, but no } \\
\text { further legislation (in this } \\
\text { case a government } \\
\text { regulation) following to } \\
\text { regulate direct uses. } \\
\text { Legislated in GL27, but no } \\
\text { further legislation (in this } \\
\text { case is a government } \\
\text { regulation) following to } \\
\text { regulate direct uses. } \\
\text { Legislated by local } \\
\text { government regulations } \\
\text { for common spring water } \\
\text { and groundwater uses }\end{array}$ & NA \\
\hline Japan & $\begin{array}{l}\text { No, but of hot spring law } \\
\text { for drilling }\end{array}$ & $\begin{array}{l}\text { No, but of hot spring law } \\
\text { for drilling }\end{array}$ & $\begin{array}{l}\text { No, but of hot } \\
\text { spring law for } \\
\text { drilling }\end{array}$ \\
\hline South Korea & Possibly & Possibly & - \\
\hline Philippines & Separate & NA & NA \\
\hline Thailand & No & No & No \\
\hline Viet Nam & $\begin{array}{l}\text { No, but mining legislation } \\
\text { applied for hot water }\end{array}$ & $\begin{array}{l}\text { No, but mining legislation } \\
\text { applied for hot water }\end{array}$ & No \\
\hline
\end{tabular}

GSHP = ground source heat pump, GL27 = Geothermal Law No. 27 of Year 2003, NA = not applicable Source: Compiled by authors. 
Table 3.4-3. What Licences Are Required?

\begin{tabular}{|c|c|c|c|}
\hline Country & Power generation & Direct use & GSHP \\
\hline China & $\begin{array}{l}\text { Qualifications for design } \\
\text { and implementation }\end{array}$ & $\begin{array}{l}\text { Qualifications for design } \\
\text { and implementation }\end{array}$ & $\begin{array}{l}\text { Qualifications for } \\
\text { design and } \\
\text { implementation }\end{array}$ \\
\hline Indonesia & $\begin{array}{l}\text { Geothermal business } \\
\text { licence }\end{array}$ & $\begin{array}{l}\text { Spring and ground water } \\
\text { uses, tourism licence }\end{array}$ & NA \\
\hline Japan & $\begin{array}{l}\text { 1) Drilling in hot spring } \\
\text { area, 2) environmental } \\
\text { assessment (if } 9 \mathrm{MW}<\text { ), 3) } \\
\text { construction in natural } \\
\text { park, 4) usage of river } \\
\text { water, etc. (conditional) }\end{array}$ & $\begin{array}{l}\text { 1)Drilling in hot spring } \\
\text { area, 2) construction in } \\
\text { natural park (if located in } \\
\text { national park) }\end{array}$ & None \\
\hline South Korea & - & - & - \\
\hline Philippines & $\begin{array}{l}\text { Department of Energy } \\
\text { (DOE) certificate of } \\
\text { registration, DOE } \\
\text { certificate of } \\
\text { accreditation, registration } \\
\text { with board of } \\
\text { investments, certificate } \\
\text { of endorsement by DOE }\end{array}$ & NA & NA \\
\hline Thailand & None & None & None \\
\hline Viet Nam & $\begin{array}{l}\text { 1) Exploration of hot } \\
\text { water, 2) exploitation of } \\
\text { hot water, 3) investment, } \\
\text { 4) environmental } \\
\text { protection, 5) } \\
\text { construction of power } \\
\text { plant, 6) producing } \\
\text { electricity }\end{array}$ & $\begin{array}{l}\text { 1) Exploration of hot } \\
\text { water, 2) exploitation of } \\
\text { hot water, 3)investment, } \\
\text { 4) environmental } \\
\text { protection depending on } \\
\text { a certain projects. }\end{array}$ & NA \\
\hline
\end{tabular}

Source: Compiled by authors. 
Table 3.4-4. Who Is the Licensing Authority?

\begin{tabular}{|c|c|c|c|}
\hline Country & Power generation & Direct use & GSHP \\
\hline China & $\begin{array}{l}\text { National development and } \\
\text { reforming committee and } \\
\text { DRC for } \\
\text { provinces/registrations }\end{array}$ & $\begin{array}{l}\text { Ministry of land and } \\
\text { Resources }\end{array}$ & $\begin{array}{l}\text { Ministry of Land } \\
\text { and Resources }\end{array}$ \\
\hline Indonesia & $\begin{array}{l}\text { Local government or } \\
\text { Minister of Energy } \\
\text { and Mineral } \\
\text { Resources }\end{array}$ & Local government & - \\
\hline Japan & $\begin{array}{l}\text { 1) Prefecture government } \\
\text { under supervision of MOE, } \\
\text { 2),3) MOE, 4) MLITT }\end{array}$ & $\begin{array}{l}\text { Ministry of } \\
\text { Environment (MOE) }\end{array}$ & $\begin{array}{l}\text { Ministry of Land, } \\
\text { Infrastructure, } \\
\text { Transport and } \\
\text { Tourism (MLITT) }\end{array}$ \\
\hline South Korea & - & - & $\begin{array}{l}\text { Korea Energy } \\
\text { Management } \\
\text { Corporation } \\
\text { (KEMCO) }\end{array}$ \\
\hline Philippines & $\begin{array}{l}\text { DOE thru Renewable } \\
\text { Energy Management } \\
\text { Bureau }\end{array}$ & NA & NA \\
\hline Thailand & Ministry of Energy & Ministry of Energy & Ministry of Energy \\
\hline Viet Nam & $\begin{array}{l}\text { 1), 2) Ministry of Natural } \\
\text { Resources and Environment } \\
\text { 3)-6) See below* }\end{array}$ & $\begin{array}{l}\text { The permits are } \\
\text { depending on the } \\
\text { scale of the project. }\end{array}$ & NA \\
\hline
\end{tabular}

Note: *Viet Nam:

3) Ministry of Planning and Investment (If the investment capital > US\$50 million) or Provincial People's Committee (If the investment capital US\$50 million). 4) Ministry of Natural Resources and Environment, 'Provincial and of Natural Resources and Environment' or the 'People's Committee of District' depends on types or scales of the projects. $5)$, 6) Ministry of Trade and Industry (if the power plant > 3MWe) (Road Map), Provincial People's Committee (if the power plant < 3MWe).

Source: Compiled by authors. 
Table 3.4-5. Is it Taxable?

\begin{tabular}{l|l|l|l|}
\multicolumn{1}{c}{ Country } & \multicolumn{1}{c}{ Power Generation } & \multicolumn{1}{c|}{ Direct Use } & \multicolumn{1}{c|}{ GSHP } \\
\hline China & Yes* & Yes* & Yes* \\
\hline Indonesia & $\begin{array}{l}\text { Property tax, income tax, } \\
\text { forestry fee, royalties }\end{array}$ & $\begin{array}{l}\text { Property tax, income tax, } \\
\text { forestry fee, royalties }\end{array}$ & No \\
\hline Japan & No & No & No \\
\hline $\begin{array}{l}\text { South } \\
\text { Korea }\end{array}$ & No & No & No \\
\hline $\begin{array}{l}\text { Philippines } \\
\text { Thailand }\end{array}$ & Yes, for the first 7 years & No & No \\
\hline Viet Nam & No & No & No \\
\hline
\end{tabular}

*China: The owner of the enterprise (power generation, direct use, GSHP) should pay tax generally. Source: Compiled by authors.

\subsection{Financial Capacities}

Tables 3.5-1 to 3.5-4 show current status of financial capacities for geothermal power generation, direct use and GSHP in each country.

Table 3.5-1. Does a Drilling Risk Guarantee Exist?

\begin{tabular}{|c|c|c|}
\hline Country & Power Generation & Direct Use \\
\hline China & No & No \\
\hline Indonesia & No & No \\
\hline Japan & $\begin{array}{l}\text { Yes, Ministry of Economy, Trade and Industry (METI) } \\
\text { supports half of drilling cost for each production well. } \\
\text { Successful drilling, money is paid back to developer. }\end{array}$ & No \\
\hline South Korea & No & No \\
\hline Philippines & $\begin{array}{l}\text { No. But there are foreign insurance companies which is } \\
\text { an option of the steam field developer. }\end{array}$ & NA \\
\hline Thailand & No & No \\
\hline Viet Nam & No & No \\
\hline
\end{tabular}

NA = not applicable.

Source: Compiled by authors. 
Table 3.5-2. Are There Companies Specialised in Geothermal Projects?

(planning, drilling, field testing, reservoir engineering, production)

\begin{tabular}{|c|c|c|c|}
\hline Country & Power Generation & Direct Use & GSHP \\
\hline China & $\begin{array}{l}\text { Yes. Jiangxi Huadian } \\
\text { Electric Power Co. Ltd. }\end{array}$ & $\begin{array}{l}\text { Yes. Sinopec Star } \\
\text { Petroleum Co. Ltd. } \\
\text { and Sichuan Kangsun } \\
\text { Energy Development } \\
\text { Co. Ltd. }\end{array}$ & Yes, a lot \\
\hline Indonesia & Yes & No & No \\
\hline Japan & Yes, many & Yes, but only few & $\begin{array}{l}\text { Yes, a few } \\
\text { consultants, } \\
\text { drilling and } \\
\text { TRT exist. }\end{array}$ \\
\hline South Korea & $\begin{array}{l}\text { Yes, a few for project } \\
\text { development }\end{array}$ & - & $\begin{array}{l}\text { Yes, there } \\
\text { are many } \\
\text { and covers } \\
\text { all aspects. }\end{array}$ \\
\hline Philippines & $\begin{array}{l}\text { Yes, only EDC has } \\
\text { technical ability for } \\
\text { entire geothermal value } \\
\text { chain, while others } \\
\text { provide only for varying } \\
\text { stages of exploration, } \\
\text { development and } \\
\text { production (e.g. PGPC, } \\
\text { Aragorn Power, Petro } \\
\text { Energy Resources, etc.) }\end{array}$ & NA & NA \\
\hline Thailand & No & No & No \\
\hline Viet Nam & No & No & No \\
\hline
\end{tabular}


Table 3.5-3. Are There Financial Institutions Providing R\&D Grants or Banks Providing Development Loans and/or Guarantees?

\begin{tabular}{c|l}
\hline Country & \\
\hline \hline China & $\begin{array}{l}\text { Yes. Banks provide loans for GSHP project mainly, but also for direct } \\
\text { use and power generation projects. Governments provide grants of } \\
\text { energy saving for DU and GSHP. } \\
\text { Loans from national agencies: Geothermal fund/loans provided by } \\
\text { Government Investment Agency, by government owned banks. } \\
\text { Yes, METI (JOGMEC and NEDO) support R\&D. JOGMEC mainly } \\
\text { support for exploration and drilling and NEDO support for facilities } \\
\text { (small binary, scale, etc.). MEXT supports for new technology } \\
\text { including EGS. } \\
\text { Japan }\end{array}$ \\
South Korea & $\begin{array}{l}\text { Yes, KETEP as a government funding agency; KEMCO for various } \\
\text { subsidies and long-term, low-interest loans. } \\
\text { Non-government-related in general. GOCCS would tap WB-IFC and } \\
\text { JBIC for funding needs. For private sector, loans are given by large } \\
\text { Thilippines } \\
\text { local banks } \\
\text { Yes, Department of Groundwater Resources (DGR), PTT Public } \\
\text { Company Limited (PTT), and Department of Alternative Energy } \\
\text { Development and Efficiency (DEDE) } \\
\text { Yes, Energy and Environment Partnership with the Mekong Region } \\
\text { (EEP), WB, ADB, NDF and UNDP. }\end{array}$ \\
\hline
\end{tabular}

Note: $\mathrm{ADB}=$ Asian Development Bank, $\mathrm{DU}=$ direct Use, GOCC $=$ Government-owned and controlled corporation, GSHP = ground source heat pump, IFC = International Finance Corporation, JBIC = Japan Bank for International Cooperation, JOGMEC = Japan oil, Gas and Metals National Corporation, KETEP = Korea Institute of Energy and Technology Evaluation and Planning, KEMCO = Korea Energy Management Corporation, METI = Ministry of Economy, Trade and Industry, Japan, MEXT = Ministry of Education, Culture, Sports, Science and Technology, Japan, NEDO $=$ New Energy and Industrial Technology Development Organization, Japan, NDF $=$ Nordic Development Fund, R\&D = research and development, UNDP $=$ The United Nations Development Programme, WB = World Bank.

Source: Compiled by authors. 
Table 3.5-4. Are There Private Investors?

\begin{tabular}{|c|c|c|}
\hline Country & Power Generation & Direct Use \\
\hline China & $\begin{array}{l}\text { Yes, Jiangxi Huadian Electric } \\
\text { Power Co. Ltd. }\end{array}$ & $\begin{array}{l}\text { Yes. Sichuan Kangsun Energy } \\
\text { Development Co. Ltd. }\end{array}$ \\
\hline Indonesia & Yes & $\begin{array}{l}\text { Yes. Limited for bathing and } \\
\text { tourism }\end{array}$ \\
\hline Japan & Yes & Yes \\
\hline South Korea & Only a few & Some for GSHPs \\
\hline Philippines & $\begin{array}{l}\text { Yes, they are directly involved in } \\
\text { exploration, delineation and } \\
\text { development. (e.g. EDC, PGPC, } \\
\text { PNOC renewables, etc.) }\end{array}$ & NA \\
\hline Thailand & None & None \\
\hline Viet Nam & Yes & Yes \\
\hline
\end{tabular}

EDC $=$ Energy Development Corporation, Philippines, GSHP = ground source heat pump, PGPC = Philippine Geothermal Production Company, PNOC = Philippine National Oil Company.

Source: Compiled by authors.

\section{Summary of current status and recommendation to policymakers}

- Drilling risk is not guaranteed except in Japan. Governments should subsidise the cost of exploration drilling and create laws for cost recovery of geothermal development to encourage private investment.

- Countries which do not have expertise, equipment, and manpower should be supported by countries with expertise through bilateral agreements.

- Governments should support R\&D through the agency not by bank-loans.

- For development, low interest loans by the Asian Development Bank, the Japan International Cooperation Agency, or the World Bank are available in most countries. Governments should promote these systems to local developers and/or investors. 


\subsection{Supportive Measures}

Supportive measures for geothermal energy use by the government in each country are described below.

\section{China}

- The government support through the national 'Guidelines on Promoting Geothermal Energy Development and Utilisation' for power generation, direct use, and GSHP.

- Subsidy of electricity price for grid (for power generation) will be introduced as another support. GSHP projects will pay for electricity by lower residential electricity price (used to pay higher industrial electric price.)

- There is no RPS or FiT for geothermal power generation. FiT and RPS for wind power and solar PV power exist.

\section{Indonesia}

- The government provides initial surface geo-scientific data for each green geothermal working area.

- Electricity price subsidies, but for all sources (not only geothermal).

- Indonesian government assignment for national electrical company to buy electricity produced by using geothermal.

- Tax incentives for power generation are also implemented (tax incentives for material/equipment importation).

- Feed-in Tariff: MEMR Regulation No. 22/2012; however not effective yet (higher price is expected).

- Ceiling price only for geothermal: Minister of Energy and Mineral Resources (MEMR) Regulation No. 02/2011, ceiling at 9.7 US cents/kWh. But the price of geothermal electricity will be decided (would be raised) based on the cost at each place (11.8-29.6 US cents/kWh, targeted to be issued June 2014).

\section{Japan}

- Electricity: The government provides subsidy for exploration well drilling (up to 50 percent) and PA activities (100 percent).

- R\&D supported by the government.

- FiT Law for renewable energy including geothermal power generation was enacted in 2012:

$\checkmark$ For $15 \mathrm{MW}$ or larger geothermal power plant (GPP), FiT price is $27.3 \mathrm{JPY} / \mathrm{kWh}$ for 15 years.

$\checkmark$ For GPP smaller than15 MW, FiT price is $42 \mathrm{JPY} / \mathrm{kWh}$ for 15 years.

Comment: The FiT price for smaller class was set for promoting smaller binary systems. 15 years is normal payback period for commercial geothermal power 
production with power cost of $20 \mathrm{JPY} / \mathrm{kWh}$.

- Heat pump installation is subsidised by federal and local government.

- Other support includes a subsidy based on the Act on Special Grants to Local Governments and Other Special Measures concerning Local Public Finance.

\section{South Korea}

- Electricity: RPS in South Korea has become an effective substitute for FiT since 2012. Geothermal energy was included in 2014 with highest REC (of 2.0).

- Heat pump: Strong government subsidy programmes and mandatory renewable energy act for heat pumps. In 2012, the Mandatory Public Renewable Energy Use Act was amended.

\section{Philippines}

- The government provides benefits across the production chain:

$\checkmark$ Share reduction from 6 percent to 1.5 percent gross income for geothermal

$\checkmark$ Subsidies for R\&D through RE Trust Fund

$\checkmark$ Duty-free importation for 10 years

$\checkmark$ Special realty tax not to exceed 1.5 percent of original costs

$\checkmark$ And many more...

- Other support: RE Act provides fiscal and non-fiscal incentives for RE investors.

- RE Act also provides for establishment of Renewable Portfolio Standard (RPS) system. (No FiT for geothermal but for wind and solar.)

\section{Thailand}

- There are governmental supportive measures for R\&D, but no other support such as tax incentives, royalty, exemptions, nor FiT or RPS (FiT for other RE but not for geothermal because there are no cost data for geothermal yet).

\section{Viet Nam}

- Government has not provided supportive measures for geothermal yet. (FiT for wind power exists and other support for solar power exists, though.)

- Research project on geothermal potential survey.

Tables 3.6-1 and 3.6-2 summarise the supportive measures in each country from three aspects, law \& programmes, financial support (subsidies, tax royalty, and exemptions), and FiT or RPS. 
Table 3.6-1. Supportive Measures in Each Country

(Legal and Financial Support)

\begin{tabular}{|c|c|c|c|c|c|c|}
\hline \multirow[t]{2}{*}{ Country } & \multicolumn{3}{|c|}{$\begin{array}{c}\text { Does national supporting } \\
\text { programme exist? (Law \& } \\
\text { programmes) }\end{array}$} & \multicolumn{3}{|c|}{$\begin{array}{l}\text { Other support (subsidies, tax incentives, } \\
\text { royalty, exemptions) }\end{array}$} \\
\hline & $\begin{array}{c}\text { Power } \\
\text { Generation }\end{array}$ & Direct Use & GSHP & Power Generation & $\begin{array}{c}\text { Direct } \\
\text { Use }\end{array}$ & GSHP \\
\hline China & Yes & Yes & Yes & Yes & Yes & Yes \\
\hline Indonesia & Yes & No & No & Yes & No & No \\
\hline Japan & Yes & No & No & $\begin{array}{l}50 \% \text { subsidy } \\
\text { for exploration } \\
\text { drilling, } 100 \% \\
\text { subsidy for PA }\end{array}$ & No & $\begin{array}{l}\text { Yes by local } \\
\text { or federal } \\
\text { governmen } \\
\mathrm{t}\end{array}$ \\
\hline South Korea & No & No & $\begin{array}{l}\text { Yes, } \\
\text { various } \\
\text { acts }\end{array}$ & No & & $\begin{array}{l}\text { Yes, by RE } \\
\text { Act }\end{array}$ \\
\hline Philippines & Yes & $\begin{array}{l}\text { Yes, } \\
\text { recent } \\
\text { DOE } \\
\text { program } \\
\text { me } \\
\end{array}$ & $\begin{array}{l}\text { Yes, } \\
\text { recent } \\
\text { DOE } \\
\text { progra } \\
\text { mme }\end{array}$ & $\begin{array}{l}\text { Yes, RE Act } \\
\text { incentives } \\
\text { (fiscal \& non- } \\
\text { fiscal); subsidy } \\
\text { only for R\&D }\end{array}$ & No & No \\
\hline Thailand & $\begin{array}{l}\text { Yes but not } \\
\text { explicitly } \\
\text { for } \\
\text { geotherma } \\
\text { I }\end{array}$ & No & No & $\begin{array}{l}\text { No royalty, no } \\
\text { tax incentives }\end{array}$ & No & No \\
\hline Viet Nam & $\begin{array}{l}\text { Yes but not } \\
\text { explicitly } \\
\text { for } \\
\text { geotherma } \\
\text { I }\end{array}$ & No & No & $\begin{array}{l}\text { No } \\
\text { government } \\
\text { support }\end{array}$ & No & No \\
\hline
\end{tabular}

DOE = Department of Energy, Philippines, $\mathrm{PA}=$ public acceptance, $\mathrm{RE}=$ renewable energy, $\mathrm{R} \& \mathrm{D}=$ research and development.

Source: Compiled by authors. 
Table 3.6-2. Supportive Measures in Each Country (FiT or RPS)

\begin{tabular}{|c|c|c|c|}
\hline \multirow[t]{2}{*}{ Country } & \multicolumn{3}{|c|}{ Are there FiT or RPS? } \\
\hline & Power Generation & Direct Use & GSHP \\
\hline China & No RPS for geothermal & No & $\begin{array}{l}\text { Subsidy for Energy Saving } \\
\text { of Building. Grant for } \\
\text { Demonstration of } \\
\text { Renewable Energy }\end{array}$ \\
\hline Indonesia & $\begin{array}{l}\text { in future (ceiling price increase } \\
@ 11.8-29.6), \text { tax incentives }\end{array}$ & No & No \\
\hline Japan & $\begin{array}{l}\text { yes, .>15 MW } \\
(\sim 27 \mathrm{JPY} / \mathrm{kWh}) ;<15 \\
(\sim 42 \mathrm{JPY} / \mathrm{kWh})\end{array}$ & No & No \\
\hline South Korea & RPS with REC of 2.0 & No & $\begin{array}{l}\text { No but discussing about } \\
\text { Renewable Heat } \\
\text { Obligation }\end{array}$ \\
\hline Philippines & $\begin{array}{l}\text { Yes, RPS but no FiT for } \\
\text { geothermal, FiT for wind/solar }\end{array}$ & No & No \\
\hline Thailand & No FiT/RPS & No & No \\
\hline Viet Nam & No & No & No \\
\hline
\end{tabular}

RPS = Renewable Portfolio Standard, MW = megawatt, kWh = kilowatt hour, JPY = Japanese Yen, REC = Renewable Energy Certificate, FiT = Feed in Tariff.

Source: Compiled by authors.

\section{Recommendation for policymakers on power generation}

- FiT for geothermal is recommended for the countries in which geothermal business is not matured.

- High credit in RPS (mandate) is recommended (for example, 10 percent in Philippines).

- National programmes should be provided explicitly for geothermal power generation, with provision of fiscal and non-fiscal incentives, ex. Tax-exemptions, royalties, subsidies, etc.

- For risk management in exploration stage, some support from the government is desirable. Subsidies for exploration drilling (for example, in Japan 50 percent) are recommended.

- Continuous R\&D support from the government is very important no matter how much geothermal power generation is materialised.

- Like Indonesia, the government should conduct basic resource surveys (temperature distribution, geothermal model based on 3G [geological, geochemical, and geophysical] data).

- International cooperation is important, not only from R\&D aspect but for business aspect also. 


\section{Recommendation for policymakers on direct use and GSHP}

- Only a few countries have national programmes for direct use and GSHP. National programmes for direct use and GSHP are recommended for ALL countries.

- National programmes should be provided with the provision of fiscal and nonfiscal incentives, such as tax exemptions, royalties, and subsidies (for example, in South Korea a maximum 80 percent of GSHP installation cost for greenhouse - 30 percent from local government and 50 percent from the central government).

- Renewable heat obligation (RHO, like RPS for electricity) is recommended for promotion of renewable heat for district heating/cooling (for tropical countries)

\subsection{Information Channels for Public Awareness}

Table 3.7-1 shows the summary of information channels for public awareness on geothermal energy in each country. There is a clear analogue with social awareness shown in section 3.3; in countries where geothermal power plant has been highly installed but not GSHP, such as in Indonesia, Japan, and Philippines, geothermal power generation has information channels while GSHP does not. On the other hand, in countries where GSHP is highly installed but not geothermal power plant, such as in China and South Korea, GSHP has information channels while geothermal power generation does not. Efforts for providing information channels may be needed to promote geothermal energy use.

Table 3.7-1. Availability of Information through Certain Information Channels

\begin{tabular}{|c|c|c|c|c|c|c|c|c|c|c|c|c|}
\hline \multirow[t]{2}{*}{ Country } & \multicolumn{3}{|c|}{$\begin{array}{c}\text { Academia (public } \\
\text { schools or } \\
\text { university level) }\end{array}$} & \multicolumn{3}{|c|}{$\begin{array}{l}\text { Professional } \\
\text { societies, special } \\
\text { conference \& } \\
\text { workshops }\end{array}$} & \multicolumn{3}{|c|}{$\begin{array}{c}\text { Through media or } \\
\text { special events }\end{array}$} & \multicolumn{3}{|c|}{$\begin{array}{l}\text { Any other channel } \\
\text { (special campaigns } \\
\text { or demonstration } \\
\text { centres, etc.) }\end{array}$} \\
\hline & PG & DU & GSHP & PG & DU & GSHP & PG & DU & GSHP & PG & DU & GSHP \\
\hline China & $x$ & $\Delta$ & 0 & 0 & 0 & 0 & $\Delta$ & $\Delta$ & 0 & $x$ & $x$ & $\Delta$ \\
\hline Indonesia & $\Delta$ & $x$ & $x$ & 0 & $x$ & $x$ & $\Delta$ & $x$ & $x$ & $\Delta$ & $x$ & $x$ \\
\hline Japan & $\Delta$ & $x$ & $\Delta$ & 0 & $\Delta$ & o & 0 & $\Delta$ & 0 & $\Delta$ & $x$ & $\Delta$ \\
\hline South Korea & $\Delta$ & $x$ & 0 & $\Delta$ & $x$ & 0 & $x$ & $x$ & $\Delta$ & $x$ & $x$ & $\Delta$ \\
\hline Philippines & $\Delta$ & $x$ & $x$ & $\Delta$ & $x$ & $x$ & $\Delta$ & $x$ & $x$ & $\Delta$ & $x$ & $x$ \\
\hline Thailand & $\Delta$ & $x$ & $x$ & $\Delta$ & $x$ & $x$ & $\Delta$ & $x$ & $x$ & $\Delta$ & $x$ & $x$ \\
\hline Viet Nam & $\Delta$ & $\Delta$ & $x$ & $x$ & $x$ & $x$ & $\Delta$ & $\Delta$ & $x$ & $x$ & $x$ & $x$ \\
\hline
\end{tabular}




\section{Recommendation to policymakers}

The advantages of geothermal energy use should be advertised through any government information channel so that social awareness of geothermal energy will be raised for both the decision-making level and public citizens.

\subsection{Future Concerns}

Tables 3.8-1 to 3.8-3 show answers to the question What could/should be done to further develop geothermal use in your country on three different aspects?

Table 3.8-1. Future Concerns on Political or Governmental Support

\begin{tabular}{|c|c|c|c|}
\hline \multirow[t]{2}{*}{ Country } & \multicolumn{3}{|c|}{ Political or government support (e.g., tax or subsidy) } \\
\hline & Power generation & Direct use & GSHP \\
\hline China & $\begin{array}{l}\text { Need issue detailed rules of } \\
\text { implementation for subsidy of } \\
\text { grid electricity price. }\end{array}$ & & \\
\hline Indonesia & $\begin{array}{l}\text { Tax exemption, subsidy on } \\
\text { electricity produced by } \\
\text { geothermal (including interesting } \\
\text { electrical price scheme). } \\
\text { Government policy on small-scale } \\
\text { geothermal development, } \\
\text { especially in the eastern parts } \\
\text { and rural parts. }\end{array}$ & $\begin{array}{l}\text { Government policy } \\
\text { on direct uses } \\
\text { application, } \\
\text { especially for } \\
\text { agriculture crops } \\
\text { processing. }\end{array}$ & \\
\hline Japan & $\begin{array}{l}\text { Further deregulation (for } \\
\text { development near hot spring } \\
\text { resorts and inside national park), } \\
\text { to shorter lead-time including } \\
\text { environment assessment, } \\
\text { continuity of support, R\&D }\end{array}$ & $\begin{array}{l}\text { Education } \\
\text { (enlightenment) }\end{array}$ & Expansion of subsidy \\
\hline South Korea & $\begin{array}{l}\text { Proper legislation, high REC in } \\
\text { RPS, risk guarantee scheme }\end{array}$ & NA & $\begin{array}{l}\text { Proper legislation } \\
\text { guaranteeing } \\
\text { optimum design and } \\
\text { installation }\end{array}$ \\
\hline Philippines & $\begin{array}{l}\text { Government regulatory agencies } \\
\text { must pave the way for the IPP's } \\
\text { to explore and develop } \\
\text { geothermal resources. Regulators } \\
\text { must provide easy access to } \\
\text { environmental permits, local } \\
\text { community permits, and local } \\
\text { government unit endorsements. }\end{array}$ & & \\
\hline Thailand & R\&D support from overseas & $\begin{array}{l}\text { R\&D support from } \\
\text { overseas }\end{array}$ & $\begin{array}{l}\text { R\&D support from } \\
\text { overseas }\end{array}$ \\
\hline Viet Nam & $\begin{array}{l}\text { legal framework, } \\
\text { more R\&D investment }\end{array}$ & Provide subsidy & $\begin{array}{l}\text { More R\&D } \\
\text { investment }\end{array}$ \\
\hline
\end{tabular}


Table 3.8-2. Future Concerns on Technology and/or Instrument

\begin{tabular}{|c|c|c|c|}
\hline \multirow[t]{2}{*}{ Country } & \multicolumn{3}{|c|}{ From the point of view of technology and/or instrument } \\
\hline & Power generation & Direct use & GSHP \\
\hline China & $\begin{array}{l}\text { Research for big capacity ( }>5 \\
\text { MWe) of geothermal power } \\
\text { generation set. } \\
\text { The capacity factor in } \\
\text { Yangbajain GPP is little lower } \\
\text { than world average due to } \\
\text { low technical level of local } \\
\text { workers and lower efficiency } \\
\text { of domestic-made generator. }\end{array}$ & $\begin{array}{l}\text { Research on } \\
\text { improvement of } \\
\text { reinjection } \\
\text { techniques for } \\
\text { sandstone } \\
\text { reservoir }\end{array}$ & $\begin{array}{l}\text { Research for efficiency } \\
\text { increasing }\end{array}$ \\
\hline Indonesia & $\begin{array}{l}\text { Small-scale and binary } \\
\text { technologies }\end{array}$ & $\begin{array}{l}\text { Agriculture crop } \\
\text { processing }\end{array}$ & \\
\hline Japan & $\begin{array}{l}\text { High efficiency EGS, high } \\
\text { resolution monitoring of } \\
\text { reservoir and its } \\
\text { surroundings, sustainable } \\
\text { low temperature binary } \\
\text { system }\end{array}$ & $\begin{array}{l}\text { Case studies of } \\
\text { cascade and multi- } \\
\text { purpose use }\end{array}$ & $\begin{array}{l}\text { Lower drilling cost, } \\
\text { heat-pump specialised } \\
\text { for GSHP with higher } \\
\text { performance, } \\
\text { nationwide suitability } \\
\text { map. }\end{array}$ \\
\hline South Korea & $\begin{array}{l}\text { Customising deep drilling } \\
\text { and well completion } \\
\text { technologies R\&D on } \\
\text { reservoir engineering and } \\
\text { monitoring technologies }\end{array}$ & NA & $\begin{array}{l}\text { Providing subsurface } \\
\text { information to enhance } \\
\text { performance of GSHP }\end{array}$ \\
\hline Philippines & $\begin{array}{l}\text {-Tackling corrosive fluids } \\
\text { (acidic reservoirs) } \\
\text {-Making the corrosion- } \\
\text { resistant materials more } \\
\text { affordable } \\
\text {-Commercial use of acid } \\
\text { inhibition chemicals }\end{array}$ & & \\
\hline Thailand & Need experience & Need experience & Need experience \\
\hline Viet Nam & technology and instrument & experiences & $\begin{array}{l}\text { technology and } \\
\text { instrument }\end{array}$ \\
\hline
\end{tabular}

$\mathrm{MW}_{\mathrm{e}}=$ megawatt electric, GPP = geothermal power plant, EGS = enhanced geothermal system, GSHP = ground source heat pump.

Source: Compiled by authors. 
Table 3.8-3. Future Concerns from Social and/or Economic Viewpoint

\begin{tabular}{|c|c|c|c|}
\hline & Power generation & Direct use & GSHP \\
\hline China & $\begin{array}{l}\text { Enhance strategic } \\
\text { consideration for } \mathrm{CO}_{2} \\
\text { emission reduction, } \\
\text { especially for keeping } \\
\text { original ecology in Tibet }\end{array}$ & - & - \\
\hline Indonesia & $\begin{array}{l}\text { Social aspect: dissemination } \\
\text { of advantage of geothermal } \\
\text { energy development }\end{array}$ & $\begin{array}{l}\text { Economical study on } \\
\text { direct uses } \\
\text { application, } \\
\text { especially for } \\
\text { agriculture crops } \\
\text { processing }\end{array}$ & - \\
\hline Japan & $\begin{array}{l}\text { Public acceptance especially } \\
\text { to hot spring owners }\end{array}$ & Public acceptance & $\begin{array}{l}\text { Education } \\
\text { (enlightenment), } \\
\text { legally binding } \\
\text { promotion action } \\
\text { (like South Korea) }\end{array}$ \\
\hline South Korea & $\begin{array}{l}\text { Promotion of geothermal } \\
\text { among public and providing } \\
\text { public risk } \\
\text { guarantee/insurance scheme }\end{array}$ & NA & $\begin{array}{l}\text { Standardisation: } \\
\text { standard procedure } \\
\text { for optimal design of } \\
\text { GSHP to avoid over- } \\
\text { design }\end{array}$ \\
\hline Philippines & $\begin{array}{l}\text { Local government meddling } \\
\text { into the commercial affairs } \\
\text { of the IPPs, stricter } \\
\text { environmental rules on } \\
\text { permitting process which } \\
\text { delays the project start-up, } \\
\text { non-supportive indigenous } \\
\text { and local people }\end{array}$ & \multicolumn{2}{|c|}{$\begin{array}{l}\text { Develop geothermal resource for direct use } \\
\text { such as heating and cooling in different } \\
\text { sectors - household, agriculture, } \\
\text { aquaculture, industrial processes, as well as } \\
\text { GSHPs }\end{array}$} \\
\hline Thailand & Case study & Case study & Case study \\
\hline Viet Nam & Social awareness & Social awareness & Social awareness \\
\hline
\end{tabular}

NA = not applicable, IPP =

Source: compiled by authors 
Tables 3.8-1 to 3.8-3 suggest that demonstration and education, for all power generation, direct use, and GSHP, are needed to raise social awareness and public acceptance in the regions where geothermal exploitation is not yet advancing.

\section{Recommendations for policymakers on power generation}

- National programmes and development plans should be provided explicitly for geothermal power generation, with provision of fiscal and non-fiscal incentives, ex. Tax-exemptions, royalties, subsidies, etc.

- Enactment of a law inside a national park to isolate a certain area for geothermal development (Energy Zone) and to balance energy development with national forest conservation.

- Government should support through agencies to reduce long process of securing environmental permit for exploration.

- One-stop-shop for securing various permits and documentation for geothermal exploration and development is strongly recommended. (Not going to national and local, and environmental and other government agencies)

- Small-scale geothermal development programme for islands and remote rural areas (separated from the national grid) is recommended, with financial incentives and subsidies from government.

- International cooperation is recommended for the countries where geothermal power has not been intensively used and no technology developed.

- Geothermal Law should be provided explicitly for geothermal development, separate from Mining Law or Hot Spring Law.

- Continuous R\&D support from the government is very important no matter how much geothermal power generation is materialised.

- Geothermal education course should be provided in university level.

- For example, in the Philippines, geothermal engineering course is supported by the EDC (a private company) with the local universities in the geothermal sites.

- International geothermal training course is provided by UNU, Auckland Univ., and Japanese universities through NEF (New Energy Foundation). Beside internet, other information channel may be needed.

- From the technological view point, each country has different future concerns. Therefore international collaboration, not only in the Asian region, but through worldwide information channels, should be provided in a practical manner, which is effective to increase human capacity.

- For countries with such specific problems, they should initiate collaborate research with countries having solutions to these problems. 
- Geothermal education programme and awareness of local people for public acceptance of geothermal development, emphasising advantage of geothermal power is needed.

\section{Recommendations for policymakers on direct use and GSHP}

- National programmes should be provided for direct use and GSHP in viewpoint of green-energy, with provision of fiscal and non-fiscal incentives, ex. Tax-exemptions, royalties, subsidies, etc.

- From a technological view point, each country has different future concerns. Therefore international collaboration, not only in the Asian region, but through worldwide information channels, should be provided in a practical manner, which is effective to increase human capacity.

- Geothermal education programme and awareness of local people for public acceptance of geothermal direct use, emphasising advantage of geothermal heat is needed.

\subsection{International Cooperation}

Table 3.9-1 shows on-going international R\&D frameworks and/or frameworks needed to foster further development in each country. China, Thailand, and Viet Nam emphasise the necessity of international cooperation. Among these three countries, China is interested in EGS mostly, while the other two countries need case studies of small scale binary systems. Government supported international R\&D frameworks are active only in South Korea and Japan. 
Table 3.9-1. Ongoing International R\&D Frameworks and/or Frameworks Needed for Further Development

\section{Country International R\&D frameworks}

\begin{tabular}{|c|c|}
\hline China & $\begin{array}{l}\text { International cooperation is necessary for learning new technology and } \\
\text { equipment from the world, especially in EGS research and } \\
\text { development. }\end{array}$ \\
\hline Indonesia & IGA activities (through Indonesia Geothermal Association) \\
\hline Japan & $\begin{array}{l}\text { - Bilateral study cooperation of micro seismicity for EGS with the United } \\
\text { States. } \\
\text { - Bilateral collaboration between AIST and KIGAM. } \\
\text { - GSHP database project in CCOP. } \\
\text { - IGA and IEA/GIA activities. }\end{array}$ \\
\hline South Korea & $\begin{array}{l}\text { - Annexes (Annex III, VIII and XI) of IEA/GIA. } \\
\text { - Bilateral collaboration between KIGAM and AIST GSJ. }\end{array}$ \\
\hline \multirow[t]{2}{*}{ Philippines } & $\begin{array}{l}\text { - R\&D's to address specific issues by individual IPPs. } \\
\text { Currently there is no country-wide collaborative R\&D nor is there any } \\
\text { R\&D that is mandated and supported by the government on geothermal } \\
\text { energy production. }\end{array}$ \\
\hline & $\begin{array}{l}\text { Thailand needs one successful location in concrete construction before } \\
\text { some measures released in legislative control and supporting (West } \\
\text { Thailand, areas of hot springs). This can be done by providing R\&D } \\
\text { support. Case studies are needed. }\end{array}$ \\
\hline Viet Nam & $\begin{array}{l}\text { Viet Nam needs the cooperation/assistance of scientists and } \\
\text { consultants in the geothermal development field. (e-Asia (JST) for R\&D, } \\
\text { Geo-fund (World Bank) for development). }\end{array}$ \\
\hline
\end{tabular}

AIST = National Institute of Advanced Industrial Science and Technology, Japan, CCOP = Coordinating Committee for Geoscience Programs, EGS = Enhanced (Engineered) Geothermal System, GSHP = ground source heat pump, IEA/GIA = International Energy Agency/Geothermal Implementing Agreement, IGA = International Geothermal Association, IPP = Independent Power Producer, JST = Japan Science and Technology Agency, KIGAM = Korea's Institute of Geoscience and Mineral Resources, R\&D = research and development.

Source: Compiled by authors.

International R\&D frameworks found in Table 3.9-1 are:

- International Geothermal Association (IGA): China, Indonesia, Japan, and the Philippines have affiliated societies of IGA while South Korea, Thailand, and Viet Nam have private members of IGA.

- International Energy Agency - Geothermal Implementing Agreement (IEA-GIA): Only Japan and South Korea are member countries among the seven countries in this study.

- Coordinating Committee for Geoscience Programs in East and Southeast Asia (CCOP): All seven countries are member countries (with Cambodia, Malaysia, Papua New Guinea, and Singapore). 
To be active member in those international frameworks may be one solution to do effective information exchange, but still domestic support for travel costs to attend meetings are needed.

For funding from international or governmental sources, the Japan Science and Technology Agency (JST)'s bilateral R\&D framework and the World Bank's geo-fund for development may be available.

\subsection{Other Relevant Issues}

Table 3.10-1 shows other relevant issues raised from some countries to be added. Detailed explanations are shown after the table.

Table 3.10-1. Other Relevant Issues

\begin{tabular}{ll}
\hline \multicolumn{1}{c}{ Country } & Other Relevant Issues \\
\cline { 2 - 2 } South Korea & $\begin{array}{l}\text {-Need for standard guideline for statistics of geothermal } \\
\text { direct-use including GSHP }\end{array}$ \\
Philippines & $\begin{array}{l}\text { Drilling cost and Tariff: important for economics of a } \\
\text { geothermal project }\end{array}$ \\
Thailand & - One successful pilot plant in concrete construction (see Table \\
& $\begin{array}{l}\text { 3.9-1) } \\
\text { - Government subsidies for renewable energies }\end{array}$ \\
Viet Nam & -Importance of establishing one geothermal power pilot in Viet Nam \\
& to pave the way to geothermal development
\end{tabular}

GSHP = ground source heat pump.

Source: Compiled by authors.

Need for standard guideline for statistics of geothermal direct-use (Korea)

$>$ We need to have a standard guideline for statistics of geothermal direct-use including GSHP, which may be quite important in national renewable energy statistics because GSHP is getting more and more dominant direct-use type worldwide (although we must admit only three North-east Asian countries are active at the moment). Different from geothermal power generation, there is significant uncertainty in statistics of direct-use, especially in estimating produced thermal energy even assuming that the installed capacity is known. This is more serious in estimating energy use through GSHP. Under the Annex VIII Geothermal Direct Use of IEA Geothermal, we have just initiated a task to analyse each country's statistical method and to recommend a guideline. Therefore, we may consider to provide member countries' own methodology, if any, and to collaborate with IEA Geothermal for devising a better method. 
Drilling cost and Tariff (Philippines)

$>$ Drilling Cost - The costs of geothermal well drilling dictated by the prices in the oil and gas industry, and the well costs have been spiralling up for the last five years. This affects the economics of specific projects, and makes the smaller capacity projects less attractive for exploration and development.

$>$ Tariffs - Like the drilling cost, tariffs are one of the most important, if not the most important, parameter in the economics of a geothermal project. The government needs to provide additional incentives to make each project economically viable, and to continue to protect the industry for any future regulatory risks.

Government subsidies for renewable energies (Thailand)

$>$ In the future, Thailand must find new renewable energy to replace gas or coal materials which will be gone in the next 20 years. Geothermal energy is one of resources to be found throughout western Thailand (area of hot-springs, at which behaviour of possible deeper reservoir is not well-known) and can be in place as well as solar, wind, and biomass. The government subsidises extra financial support for these energy types, including R\&D. How would Thailand achieve success in further deployment of renewable energy and be good example of new development for reduction of carbon foot print is a matter of importance.

Importance of establishing one geothermal power pilot (Viet Nam)

$>$ EEP Mekong is the only ongoing project. As for the private sector in Viet Nam, two companies are investing in developing two geothermal power plants but it is a long way to get the electricity because it depends much on the fund for the projects. It is very significant if there is one geothermal power pilot in Viet Nam such as the Fang in Thailand. It is a good example to show to the people, government officials, investors then they will pay more attention on geothermal development. This pilot should be implemented by Vietnamese government with the support and assistance of international geothermal scientists and consultants.

For standard guidelines for statistics of geothermal direct-use including GSHP, a future ERIA project or other international R\&D framework such as IEA-GIA may be able to handle the issue. Drilling cost, tariffs, and government's subsidies, all matters of economics, may be investigated further in a future ERIA project if needed. For pilot plants, bilateral cooperation with government support may be effective.

\section{Recommendation to policymakers}

Bilateral agreements between governments should be provided for Thailand and Viet Nam on a pilot project, identifying agencies to implement the project. 
